$\begin{gathered}\text { Науковий вісник Нлту України } \\ \text { Scientific Bulletin of UNFU } \\ \text { https://nv.nltu.edu.ua }\end{gathered}$
$\begin{aligned} & \text { https://doi.org/10.36930/40300114 (i) ISSN 1994-7836 (print) } \\ & \text { Article received 07.02.2020 p. } \\ & \text { ISSN 2519-2477 (online) } \\ & \text { Article accepted 27.02.2020 p. } \\ & \text { UDK 504.054:582.685.4 }\end{aligned}$

Х. Б. Караванович, Н. І. Глібовицька

Івано-Франківський національний технічний університет нафти і газу, м. Івано-Франківськ, Україна

\title{
ЗДАТНІСТЬ ДЕРЕВНИХ ВИДІВ АКУМУЛЮВАТИ ВАЖКІ МЕТАЛИ В УМОВАХ НАФТОЗАБРУДНЕНИХ Г'РУНТІВ
}

Досліджено особливості акумуляції хімічних елементів деревними рослинами в умовах впливу Битків-Бабчинського
нафтового родовища. Рентгенофлуоресцентним методом встановлено концентрацію алюмінію, цинку, титану, феруму,
стронцію, нікелю, купруму, арсену, брому, рубідію, молібдену, паладію, аргентуму, плюмбуму, ванадію у сухій масі листко-
вих пластинок клена гостролистого, бука лісового, ліщини звичайної, берези повислої, липи серцелистої та осики, що зрос-
тають у забрудненому нафтопродуктами довкіллі. За допомогою програм CorelDRAW та ImageJ розраховано частку некро-
тизованої тканини асиміляційних органів деревних рослин в умовах впливу родовища. Встановлено прямо пропорційну за-
лежність між ураженням листкових пластинок дерев некрозами та накопиченням хімічних елементів рослинами. Зафіксова-
но відсутність арсену, брому, молібдену, паладію, аргентуму, плюмбуму, ванадію у листках клена, бука, липи. Виявлено
зростання вмісту хімічних елементів у асиміляційних органах дослідних дерев у такому ряді: Мо $\rightarrow \mathrm{Pb} \rightarrow \mathrm{Pd} \rightarrow \mathrm{Ag} \rightarrow \mathrm{Br} \rightarrow$
$\mathrm{As} \rightarrow \mathrm{V} \rightarrow \mathrm{Ni} \rightarrow \mathrm{Rb} \rightarrow \mathrm{Cu} \rightarrow \mathrm{Sr} \rightarrow \mathrm{Ti} \rightarrow \mathrm{Zn} \rightarrow \mathrm{Fe} \rightarrow \mathrm{Al}$. Частка некротизації листків в умовах Битків-Бабчинського нафтово-
го родовища зростає у ряді дослідних рослин: бук $\rightarrow$ клен $\rightarrow$ липа $\rightarrow$ осика $\rightarrow$ береза $\rightarrow$ ліщина. Максимальною акумуля-
тивною здатністю хімічних елементів володіє ліщина, мінімальною - бук та клен. Враховуючи значні кумулятивні ресурси
ліщини, доцільно використовувати вид як фіторемедіант забрудненого хімічними елементами довкілля. Клен та бук нале--
жать до рослин-елімінаторів, які вибірково та в невеликих кількостях поглинають токсиканти з довкілля, що зумовлено на-
явністю у цих видів потужних протекторних механізмів. Береза, липа та осика відзначаються цінними біоіндикаторними ха-
рактеристиками та іхх можна використовувати для оцінювання екологічного напруження середовища.

Ключові слова: дендроіндикація; дендроремедіація; нафтове родовище; хімічні елементи; некротичні ураження; листкові пластинки.

Вступ. Нафтове забруднення довкілля є глобальною екологічною проблемою сьогодення, а пошук шляхів до його подолання - одним із головних завдань практичної екологічної науки. Деревні насадження $є$ потужним природним фільтром широкого спектра забруднювачів антропогенного походження, що дає змогу використовувати зелені рослини як ефективні фітомеліоранти довкілля. За можливостями акумулювати у своїх тканинах токсиканти рослини поділяються на біоіндикатори, елімінатори та акумулятори. Середовищетвірна роль кожного виду індивідуальна та визначається генетично зумовленою екологічною пластичністю. Нафта містить практично всі хімічні елементи, присутні у періодичній системі, що є однією із причин негативного впливу забруднення довкілля нафтопродуктами.

Об'єкт нашого дослідження - такі деревні види, що часто застосовуються у залісенні урбанізованих територій: бук лісовий, клен гостролистий, липа серцелиста, осика, береза повисла, ліщина звичайна.

Предмет дослідження - некротичні ушкодження листкових пластинок деревних видів та накопичення хімічних елементів асиміляційними органами дослідних об'єктів.
Мета нашої роботи - виявити акумулятивні особливості домінантних деревних видів в умовах нафтового родовища та перспективи їх впровадження у залісення техногенно-забруднених екосистем.

Завдання роботи:

- дослідити рівень некротичного ураження листкових пластинок деревних порід, що ростуть в умовах Битків-Бабчинського нафтового родовища;

- вивчити особливості поглинання хімічних елементів деревними рослинами, що ростуть в умовах нафтового родовища;

- встановити взаємозв'язок між наявністю некрозів листкових пластинок дерев та їх акумулятивною здатністю;

- виявити найбільш небезпечні хімічні елементи, що стимулюють появу некрозів та передчасне старіння клітин асиміляційних органів деревних рослин;

- виділити ефективні фіторемедіанти та фітоіндикатори забрудненого довкілля нафтою, які б послужили для оцінювання та контролю за екологічною ситуацією антропогенно змінених територій.

Наукова новизна дослідження полягає у виявленні потужної металоакумуляційної здатності ліщини, що ефективно виконує фітомеліоративну функцію в умовах нафтозабруднених грунтів. Встановлено, що береза, липа й осика мають цінні біоіндикаційні характеристи-

\section{Інформація про авторів:}

Караванович Христина Богданівна, аспірант, кафедра екологіï. Email: kristina_kvitana@ukr.net

Глібовицька Наталія Ігорівна, канд. біол. наук, доцент, кафедра екології.

Email: nataly.glibovytska@gmail.com; https://orcid.org/0000-0002-6050-9664

цитування за ДСту: Караванович Х. Б., Глібовицька Н. І. Здатність деревних видів акумулювати важкі метали в умовах нафтозабруднених ґрунтів. Науковий вісник НлтУ України. 2020, т. 30, № 1. С. 83-87.

Citation APA: Karanovych, K. B., \& Glibovytska, N. I. (2020). The woody species' accumulative ability of heavy metals in the conditions of oil-polluted soils. Scientific Bulletin of UNFU, 30(1), 83-87. https://doi.org/10.36930/40300114 
ки та їх можна використовувати для моніторингу екологічного стану техногенно-трансформованих екосистем. Виявлено, що бук та клен належать до видів-елімінаторів елементів та володіють стійкістю до забруднення. Вперше виявлено, що в умовах впливу нафтового родовища інтенсивність поглинання важких металів деревними видами зростає у ряді: $\mathrm{Mo} \rightarrow \mathrm{Pb} \rightarrow \mathrm{Pd} \rightarrow \mathrm{Ag} \rightarrow \mathrm{Br}$ $\rightarrow \mathrm{As} \rightarrow \mathrm{V} \rightarrow \mathrm{Ni} \rightarrow \mathrm{Rb} \rightarrow \mathrm{Cu} \rightarrow \mathrm{Sr} \rightarrow \mathrm{Ti} \rightarrow \mathrm{Zn} \rightarrow \mathrm{Fe} \rightarrow$ Al. Встановлено посилення фітотоксичного ефекту хімічних елементів у ряді: бром $\rightarrow$ алюміній $\rightarrow$ нікель $\rightarrow$ купрум $\rightarrow$ ванадій $\rightarrow$ цинк $\rightarrow$ ферум $\rightarrow$ плюмбум $\rightarrow$ стронцій $\rightarrow$ молібден $\rightarrow$ титан $\rightarrow$ паладій $\rightarrow$ арсен $\rightarrow$ аргентум $\rightarrow$ рубідій.

Практичне значення результатів дасть змогу впроваджувати у залісення територій нафтовидобутку, а також інших забруднених хімічними елементами екосистем, стійких деревних меліорантів довкілля, так само, як і деревних індикаторів його екологічного стану.

Матеріал і методи дослідження. Дослідження виконували в умовах Битків-Бабчинського нафтового родовища, що розташоване у Надвірнянському районі Івано-Франківської області. Відбір проб рослинного матеріалу здійснювали з гілок першого порядку галуження за периметром крони дослідних дерев наприкінці вегетаційного періоду (серпень-вересень). Як об'єкти дослідження обрали клен, бук, ліщину, березу, липу та осику, що $є$ найпоширенішими деревними рослинами на територіях, прилеглих до родовища. Для дослідження підбирали по 8 модельних дерев кожного виду, відстань між якими становить до 100 м та готували змішану пробу листкового матеріалу для аналізу за апробованими методиками [12].

Частка некротизованої тканини листків визначали за допомогою комп'ютерних програм CorelDraw та ImageJ. Значення довжини і ширини та розмір скан-зображення кожного листка отримали за допомогою програми CorelDraw. Для розрахунку площі некрозу листкових пластинок використовували програму ImageJ. Для кожного виду дерева аналізували по 100 листкових пластинок.

Проби листкових пластинок кожного деревного об'єкта масою 5 г спалювали у муфельній печі за температури $800^{\circ} \mathrm{C}$ до повного перетворення листя на золу. Дослідження концентрації хімічних елементів у листках деревних видів здійснювали рентгенофлуоресцентним методом на приладі EXPERT 3L. За допомогою детекторів (PIN diode, Si(Li), Ge(Li), Silicon Drift Detector SDD) реєстрували спектри флуоресценції кожного хімічного елемента у дослідних зразках.

Аналіз літературних джерел. Важкі метали є найпоширенішою групою хімічних елементів та однією 3 причин появи некротичних пошкоджень асиміляційних органів рослин $[1,4]$. Потрапляючи в організм рослини, вони заміщають метали в активному центрі ферментів, таким чином блокують їхню активність, а також стимулюють старіння клітин, інтенсифікуючи вільнорадикальні процеси. Некротичні ушкодження є першими видимими реакціями рослини на несприятливі умови зростання та діагностичним маркером екологічного стану довкілля. Рослини поглинають важкі метали 3 різною інтенсивністю, залежно від природи металу та генетичних особливостей виду [3, 14]. Найефективнішими очисниками довкілля від хімічних елементів є акумулятори, що поглинають забруднювачі у великих кіль- костях. Такі види можна застосовувати у біологічній ремедіації забруднених територій. Фіторемедіація сьогодні є одним із найперспективніших способів відновлення порушених антропогенною діяльністю екосистем. Цей метод боротьби з забрудненням хімічними елементами, нафтопродуктами відзначається простотою, ефективністю, доступністю та економічною доцільністю $[2,13]$. У фіторемедіаційній практиці застосовують горіх волоський, осоку шорстковолосисту, елодею канадську, представників родини Бобові, які завдяки особливим метаболічним перетворенням детоксифікують токсиканти або переводять їх у недоступну для переміщення форму [7]. Зокрема, білки-хелатори металотіонеїни захоплюють метали та утримують їх у формі комплексних сполук. Вибіркове поглинання важких металів рослинами $є$ ще однією формою захисту від пошкодження, що притаманна елімінаторам елементів. Такі види також мають фізіологічні механізми блокування потрапляння токсикантів ще на межі з клітинною стінкою рослин [6].

Важливе значення під час діагностики екологічного стану довкілля мають види-індикатори, що реагують на найменші зміни параметрів довкілля низкою фізіологічних та морфологічних процесів. У літературних джерелах наведено біоіндикаційну перспективність липи серцелистої та берези звичайної стосовно виявлення забруднення довкілля важкими металами $[3,5,10,11]$.

Дослідження фітомеліоративної функції клена гостролистого та бука лісового показали їхню відносну стійкість до забруднення довкілля антропогенними контамінантами $[8,9]$. Даних стосовно акумулятивної здатності осики та ліщини європейської у сучасній науковій літературі ми не виявили. 3 погляду індикаційної та ремедіаційної функції дослідні рослини є науковим інтересом та $з$ огляду на їхній широкий ареал та репрезентативність на території моніторингу ми обрали їх як об'єкти дослідження.

Результати дослідження. Серед дослідних рослин найбільшою акумулятивною здатністю володіє ліщина, сумарний вміст елементів у тканинах якої становить $8,48 \%$ (табл. 1).

Клен та бук відзначаються найменшою поглинальною функцією елементів в умовах впливу нафтового родовища. Акумулятивні можливості хімічних елементів зростають у такому ряді дослідних рослин: клен $\rightarrow$ бук $\rightarrow$ липа $\rightarrow$ береза $\rightarrow$ осика $\rightarrow$ ліщина. Не виявлено вмісту деяких важких металів у листкових пластинках клена, бука та липи, зокрема: арсену, брому, молібдену, паладію, аргентуму, плюмбуму, ванадію.

Серед 15 досліджених хімічних елементів максимальну мобільність має алюміній, а найменше транслокується у рослини молібден. Поглинання хімічних елементів деревними видами зростає у ряді елементів: Мо $\rightarrow \mathrm{Pb} \rightarrow \mathrm{Pd} \rightarrow \mathrm{Ag} \rightarrow \mathrm{Br} \rightarrow \mathrm{As} \rightarrow \mathrm{V} \rightarrow \mathrm{Ni} \rightarrow \mathrm{Rb} \rightarrow \mathrm{Cu} \rightarrow$ $\mathrm{Sr} \rightarrow \mathrm{Ti} \rightarrow \mathrm{Zn} \rightarrow \mathrm{Fe} \rightarrow \mathrm{Al}$. При цьому найінтенсивніше поглинання усіма рослинами саме алюмінію, цинку, титану, феруму та стронцію. Накопичення інших елементів асиміляційними органами дерев відбувається на 45 порядків нижче.

В умовах нафтового родовища спостерігаємо максимальне ураження некрозами листкових пластинок ліщини - 24,46 \%, мінімальне - бука - 4,36 \% (табл. 2). Пошкодження асиміляційних органів дослідних рослин зростає у ряді: бук $\rightarrow$ клен $\rightarrow$ липа $\rightarrow$ осика $\rightarrow$ береза $\rightarrow$ ліщина. 
Табл. 1. Вміст хімічних елементів у листкових пластинках деревних рослин в умовах Битків-Бабчинського нафтогазоконденсатного родовища

\begin{tabular}{|c|c|c|c|c|c|c|}
\hline \multirow{2}{*}{$\begin{array}{c}\text { Хімічний еле- } \\
\text { мент, \% }\end{array}$} & \multicolumn{5}{|c|}{ Вид рослини } \\
\hline $\mathrm{nl}$ & 1,068700 & 1,418500 & 6,217000 & 3,798000 & 1,237000 & 1,690000 \\
\hline $\mathrm{Zn}$ & 0,089000 & 0,083000 & 0,633600 & 0,357000 & 0,106000 & 0,397000 \\
\hline $\mathrm{Ti}$ & 0,340000 & 0,080000 & 0,245000 & 0,162000 & 0,151000 & 0,186000 \\
\hline $\mathrm{Fe}$ & 0,420000 & 0,277000 & 1,087600 & 0,723000 & 0,482000 & 0,834000 \\
\hline $\mathrm{Sr}$ & 0,051100 & 0,122000 & 0,298000 & 0,205600 & 0,078000 & 0,185000 \\
\hline $\mathrm{Ni}$ & 0,000043 & 0,000040 & 0,000124 & 0,000082 & 0,000057 & 0,000093 \\
\hline $\mathrm{Cu}$ & 0,000092 & 0,000110 & 0,000256 & 0,000200 & 0,000150 & 0,000190 \\
\hline $\mathrm{As}$ & 0 & 0 & 0,000149 & 0,000013 & 0 & 0,000010 \\
\hline $\mathrm{Br}$ & 0 & 0 & 0,000086 & 0,000039 & 0 & 0,000045 \\
\hline $\mathrm{Rb}$ & 0,000041 & 0,000032 & 0,000193 & 0,000104 & 0,000042 & 0,000095 \\
\hline $\mathrm{Mo}$ & 0 & 0 & 0,000014 & 0,000005 & 0 & 0,000011 \\
\hline $\mathrm{Pd}$ & 0 & 0 & 0,000120 & 0,000022 & 0 & 0,000012 \\
\hline $\mathrm{Ag}$ & 0 & 0 & 0,000054 & 0,001300 & 0 & 0,000019 \\
\hline $\mathrm{Pb}$ & 0 & 0 & 0,000040 & 0,000017 & 0 & 0,000019 \\
\hline $\mathrm{V}$ & 0 & 0 & 0,000190 & 0,000025 & 0 & 0,000017 \\
\hline $\mathbf{2}$ & $\mathbf{1 , 9 6 8 9 7 6}$ & $\mathbf{1 , 9 8 0 6 8 2}$ & $\mathbf{8 , 4 8 2 4 2 6}$ & $\mathbf{2 , 0 5 4 2 4 9}$ & $\mathbf{2 , 0 5 4 0 9 9}$ & $\mathbf{3 , 2 9 2 5 1 1}$ \\
\hline
\end{tabular}

Табл. 2. Площа некрозів листкових пластинок деревних порід в умовах Битків-Бабчинського нафтогазоконденсатного родовища

\begin{tabular}{|c|c|c|}
\hline $\begin{array}{c}\text { № } \\
\text { 3/п }\end{array}$ & Вид рослини & $\begin{array}{c}\text { \% некротизованої тканини } \\
\text { листка }\end{array}$ \\
\hline 1 & клен гостролистий & $6,58^{ \pm 0,26}$ \\
\hline 2 & бук лісовий & $4,36^{ \pm 0,18}$ \\
\hline 3 & ліщина європейська & $24,46^{ \pm 1,05}$ \\
\hline 4 & береза звичайна & $12,55^{ \pm 0,67}$ \\
\hline 5 & липа серцелиста & $8,48^{ \pm 0,44}$ \\
\hline 6 & осика & $11,50^{ \pm 0,38}$ \\
\hline
\end{tabular}

Встановили прямо пропорційну залежність між інтенсивністю накопичення хімічних елементів листковими пластинками деревних рослин та часткою некротизації тканин.

Для візуалізації взаємозв'язків між некрозами листя дослідних дерев і вмістом важких металів у них створили графіки (рисунок). Із наведених вище графіків можна простежити лінійну залежність між вмістом важких металів і некрозами листкової пластинки дослідних дерев.

Максимальний фітотоксичний ефект має рубідій, найменший - бром. Кореляційний аналіз між вмістом елементів у листках дерев та площею некрозів показав, що небезпека забруднення хімічними елементами довкілля зростає у ряді: бром $\rightarrow$ алюміній $\rightarrow$ нікель $\rightarrow$ купрум $\rightarrow$ ванадій $\rightarrow$ цинк $\rightarrow$ ферум $\rightarrow$ плюмбум $\rightarrow$ стронцій $\rightarrow$ молібден $\rightarrow$ титан $\rightarrow$ паладій $\rightarrow$ арсен $\rightarrow$ аргентум $\rightarrow$ рубідій.

Обговорення отриманих результатів. В усіх дослідних рослин встановили наявність некротичного ураження листкових пластинок як наслідок впливу контамінантів нафтового родовища. Некрози $є$ першими видимими пошкодженнями рослинного організму, які виникають у випадку несприятливих умов росту. Основними чинниками, що зумовлюють некротизацію тканин рослин, $є$ кислотні сполуки та важкі метали, що присутні в нафті у великій кількості. Важкі метали є чинниками, що зумовлюють появу пошкоджень клітин та порушення функціонування рослинного організму $[2,6]$.

Найістотніші зміни функціонального стану організму виявили у ліщини, яка в умовах нафтового забруднення $€$ акумулятором елементів. Відсутність потужних механізмів захисту від токсикантів зумовлює передчасне старіння та загибель клітин асиміляційних органів виду. Здатність поглинати хімічні елементи широкого спектра зумовлює перспективність ліщини у ролі фіто- ремедіанта техногенно-трансформованого середовища. Відомі фіторекультиваційні властивості мають волоський горіх, обліпиха крушиновидна, верба козяча $[7,13$, 14]. Ці види впроваджуються у залісення нафтозабруднених територій завдяки можливості детоксифікувати забруднювачі у своїх тканинах.

Бук та клен відзначаються як найменшою часткою пошкодження асиміляційних органів, так і найменшою акумулятивною здатністю. Це зумовлено селективним поглинанням елементів, наявністю захисних механізмів, що перешкоджають потраплянню в організм небезпечних речовин, а також блокують транслокацію елементів по судинній системі рослин [2]. Серед дослідних рослин бук та клен $\epsilon$ найбільш пристосованими видами до нафтового забруднення. Береза, липа та осика займають проміжне положення серед дослідних об'єктів та проявляють середню стійкість до нафтового забруднення. Ці види виступають у ролі ефективних індикаторів якості довкілля $[3,4,5]$. Деревні рослини поглинають хімічні елементи 3 різною інтенсивністю та нагромаджують їх у різних кількостях. Алюміній, цинк, титан, ферум та стронцій акумулюють усі рослини у найбільших концентраціях, усі інші елементи надходять в організм фітооб'єктів у десятки тисяч разів меншої кількості. Вибірково поглинають елементи клен, липа та бук, а ліщина, осика та береза акумулюють усі 15 елементів у своїх тканинах.

Висновки. В умовах Битків-Бабчинського нафтового родовища пошкодження листкових пластинок некрозами зростає у такому ряді дослідних деревних видів: бук $\rightarrow$ клен $\rightarrow$ липа $\rightarrow$ осика $\rightarrow$ береза $\rightarrow$ ліщина. Здатність рослин поглинати важкі метали зростає у наступному ряді: клен $\rightarrow$ бук $\rightarrow$ липа $\rightarrow$ береза $\rightarrow$ осика $\rightarrow$ ліщина. Усі дослідні рослини найінтенсивніше поглинають такі елементи: алюміній, цинк, титан, ферум та стронцій. Фітотоксичність хімічних елементів нафтозабрудненого довкілля зростає у ряді: бром $\rightarrow$ алюміній $\rightarrow$ нікель $\rightarrow$ купрум $\rightarrow$ ванадій $\rightarrow$ цинк $\rightarrow$ ферум $\rightarrow$ плюмбум $\rightarrow$ стронцій $\rightarrow$ молібден $\rightarrow$ титан $\rightarrow$ паладій $\rightarrow$ арсен $\rightarrow$ аргентум $\rightarrow$ рубідій.

Рекомендовано впроваджувати у залісення нафтозабруднених та інших техногенно-трансформованих екосистем ліщину, поряд із волоським горіхом, вербою козячою та обліпихою крушиновидною, що належать до рослин-акумуляторів елементів та ефективно виконують ремедіаційну функцію. 


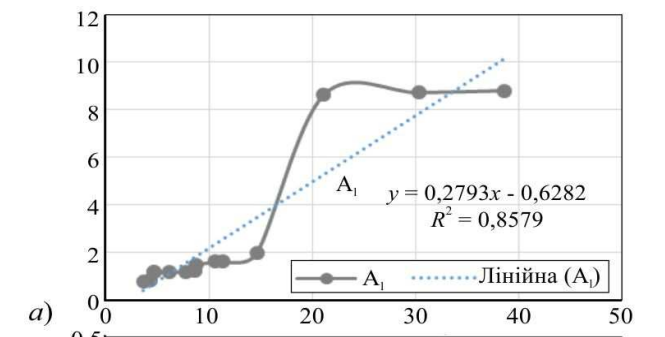$$
\text { a) } \begin{array}{llllll}
0 & 10 & 20 & 30 & 40 & 50
\end{array}
$$

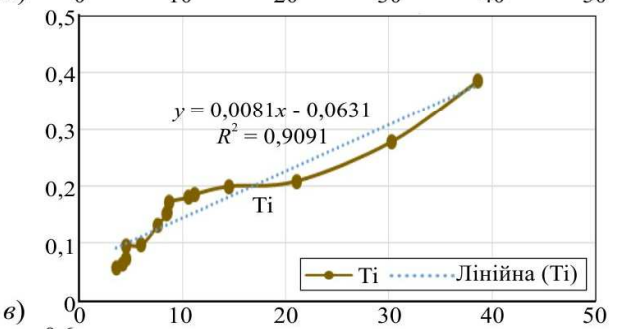

$$
\text { в) }
$$
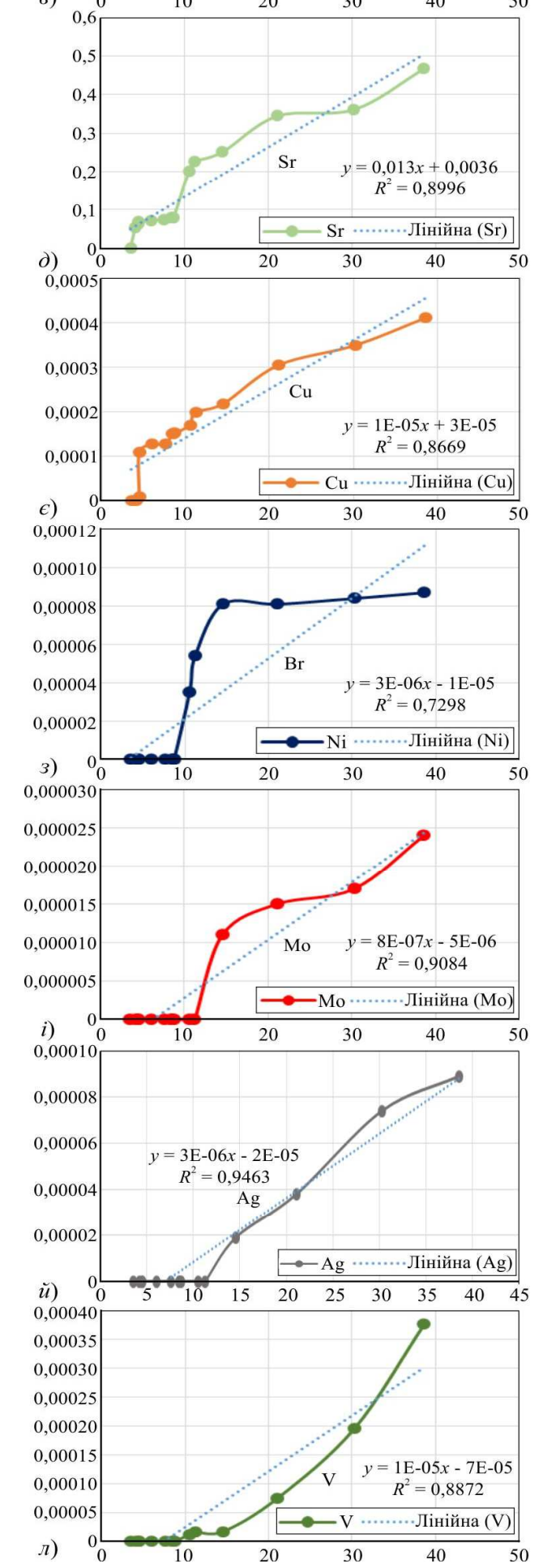
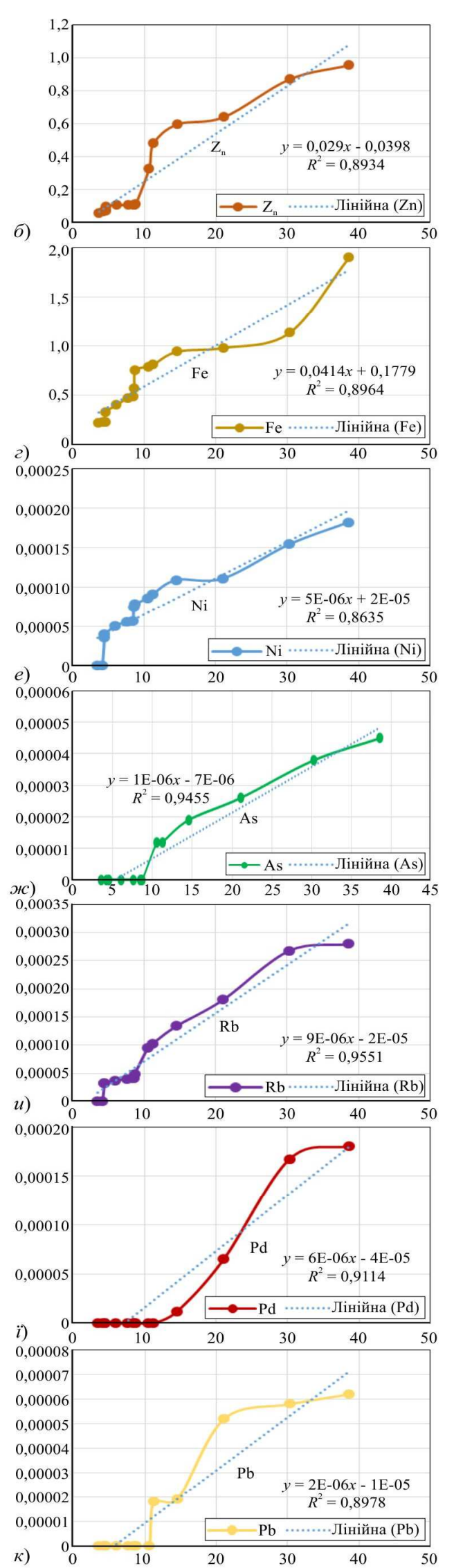

Рисунок. Залежності ступеня некротизації листків деревних видів порід від концентрації важких металів в умовах Битків-Бабчинського нафтового родовища 
Бук та клен є видами-елімінаторами елементів, що вибірково поглинають токсиканти завдяки потужним захисним механізмам. Березу, липу та осику доцільно використовувати як чутливі індикатори екологічного стану навколишнього середовища.

\section{References}

1. Birke, M., Rauch, U., \& Hofmann, F. (2018). Tree bark as a bioindicator of air pollution in the city of Stassfurt, Saxony-Anhalt, Germany. Journal of Geochemical Exploration, 187, 97117. https://doi.org/10.1016/i.gexplo.2017.09.007

2. Cristaldi, A., Conti, G., Eun HeaJho, E., Zuccarello, P., Grasso, A., Copat, C., \& Ferrante, M. (2017). Phytoremediation of contaminated soils by heavy metals and PAHs: a brief review. Environmental Technology \& Innovation, 8, 309-326. https://doi.org/10.1016/j.eti.2017.08.002

3. Erofeeva, E. A. (2015). Hormesis and Paradoxical Effects of Drooping Birch (Betula pendula Roth) Parameters Under Motor Traffic Pollution. Dose Response, 13(2). https://doi.org/10.1177/1559325815588508

4. Glibovytska, N. I., \& Karavanovych, K. B. (2018). Morphological and physiological parameters of woody plants under conditions of environmental oil pollution. Ukrainian Journal of Ecology, 8(3), 322-327.

5. Lewis, J., Qvarfort, U., \& Sjöström, J. (2015). Betula pendula: A Promising Candidate for Phytoremediation of TCE in Northern Climates. Int. J. Phytoremediation, 17(1-6), 9-15. https://doi.org/10.1080/15226514.2013.828012

6. Li, J., Zhang, D., Zhou, P., \& Liu, Q. (2018). Assessment of Heavy Metal Pollution in Soil and Its Bioaccumulation by Dominant Plants in a Lead-Zinc Mining Area, Nanjing. Huan Jing Ke Xue, 39(8), 3845-3853. https://doi.org/10.13227/j.hjkx.201712086

7. Lim, M. W., Lau, E. V., \& Poh, P. E. (2016). A comprehensive guide of remediation technologies for oil contaminated soil - Pre- sent works and future directions. Marine Pollution Bulletin, 109(1), 619-620. https://doi.org/10.1016/i.marpolbul.2016.04.023

8. Mauer, O., \& Palatova, E. (2011). Root system development of European beech (Fagus sylvatica L.) after different site preparation in the air-polluted area of the Krusne hory Mts. Beskydy, 4(2), 147-160.

9. Ord, J., Butler, H., McAinsh, M., \& Martin, F. (2016). Spectrochemical analysis of sycamore (Acer pseudoplatanus L.) leaves for environmental health monitoring. Analyst, 141(10), 2896-2903. https://doi.org/10.1039/c6an00392c

10. Pavlović, D., Pavlović, M., Marković, M., Karadžić, B., Kostić, O., Jarić, S., Mitrović, M., Gržetić, I., \& Pavlović, P. (2017). Possibilities of assessing trace metal pollution using Betula pendula Roth. leaf and bark - Experience in Serbia. Journal of the Serbian Chemical Society, 82(6), 272-276. https://doi.org/10.2298/JSC170113024P

11. Pedroso, A., Bussotti, F., Papini, A., Tani, C., \& Domingos, M. (2016). Pollution emissions from a petrochemical complex and other environmental stressors induce structural and ultrastructural damage in leaves of a biosensor tree species from the Atlantic Rain Forest. Ecological Indicators, 67, 215-226. https://doi.org/10.1016/j.ecolind.2016.02.054

12. Rudenko, S. S., Kostishin, S. S., \& Morozova, T. V. (2008). General ecology. Practical course: a textbook for students of higher education. (Part 2). Chernivtsi, $320 \mathrm{p}$.

13. Shevchyk, L. Z., \& Romanyuk, O. I. (2017). Analysis of biological methods of recovery of oil-contaminated soils. Scientific Journal ScienceRise: Biological Science, 1(4), 31-39.

14. Steindor, K. A., Franiel, I. J., Bierza, W. M., Pawlak, B., \& Palowski, B. F. (2016). Assessment of heavy metal pollution in surface soils and plant material in the post-industrial city of Katowice, Poland. J. Environ Sci Health A Tox Hazard Subst Environ Eng., 51(5), https://doi.org/10.1080/10934529.2015.1120509

K. B. Karanovych, N. I. Glibovytska

Ivano-Frankivsk National Technical University of Oil and Gas, Ivano-Frankivsk, Ukraine

\section{THE WOODY SPECIES' ACCUMULATIVE ABILITY OF HEAVY METALS IN THE CONDITIONS OF OIL-POLLUTED SOILS}

The peculiarities of chemical elements accumulation by woody plants under conditions of Bytkiv-Babchynske oil deposit influence are investigated. X-ray fluorescence concentrations of aluminum, zinc, titanium, ferum, strontium, nickel, kuprum, arsenic, bromine, rubidium, molybdenum, palladium, argentum, plumbum, and vanadium in the dry mass of Acer platanoides L., Tilia cordata Mill., Fagus sylvatica L., Populus tremula L., Betula pendula Roth., Corylus avellana L. leaves under oil-contaminated environment are determined. With the help of CorelDRAW and ImageJ programs, the percentage of necrotized tissue of woody plants assimilation organs under the conditions of oil deposit is calculated. A direct proportional relationship between the necrotic lesions of leaf blades and the accumulation of chemical elements by plants is established. Absence of arsenic, bromine, molybdenum, palladium, argentum, plumbum, vanadium in Acer platanoides, Tilia cordata, Fagus sylvatica leaves is recorded. The growing content of chemical elements in the assimilation organs of the experimental trees is revealed in the following range: $\mathrm{Mo} \rightarrow \mathrm{Pb} \rightarrow \mathrm{Pd} \rightarrow \mathrm{Ag} \rightarrow \mathrm{Br} \rightarrow \mathrm{As} \rightarrow$ $\mathrm{V} \rightarrow \mathrm{Ni} \rightarrow \mathrm{Rb} \rightarrow \mathrm{Cu} \rightarrow \mathrm{Sr} \rightarrow \mathrm{Ti} \rightarrow \mathrm{Zn} \rightarrow \mathrm{Fe} \rightarrow \mathrm{Al}$. The percentage of leaf necrotization under conditions of Bytkiv-Babchynske oil deposit is increasing in a following range of experimental plants: Fagus sylvatica $\rightarrow$ Acer platanoides $\rightarrow$ Tilia cordata $\rightarrow$ Populus tremula $\rightarrow$ Betula pendula $\rightarrow$ Corylus avellana. The maximum accumulative capacity of chemical elements is possessed by Corylus avellana L., minimum one - by Fagus sylvatica and Acer platanoides Because of the considerable cumulative resources of Corylus avellana, it is advisable to use the species as a phytoremediant of contaminated environment by chemical elements. Fagus sylvatica and Acer platanoides belong to the eliminator plants that absorb toxicants from the environment selectively and in small quantities due to the presence of powerful protective mechanisms in these species. Tilia cordata, Populus tremula and Betula pendula are marked by valuable bioindicator characteristics and can be used to assess the environmental stress level.

Keywords: dendroindication; dendroremediation; oil deposit; chemical elements; necrotic lesions; leaf plates. 